\title{
Evidence for prostaglandin involvement in early luteal regression of the superovulated nanny goat (Capra hircus)
}

\author{
K. M. Battye $\dagger$, R. J. Fairclough*, A. W. N. Cameron and A. O. Trounson
}

Centre for Early Human Development, Monash Medical Centre, 246 Clayton Road, Clayton, Victoria 3168, Australia; and *Animal Research Institute, Werribee, Victoria 3030, Australia

\begin{abstract}
Summary. Feral does of various ages were treated with intravaginal progestagen sponges for 16 days to synchronize oestrus. On Day 2 before sponge removal the goats were given 1200 i.u. PMSG to induce superovulation: 6 of the goats were also injected every $12 \mathrm{~h}$ with flunixin meglumine, a prostaglandin (PG) synthetase inhibitor, from Day 3 to 7 of the synchronized oestrous cycle. Jugular blood samples were collected from all females into heparinized syringes at daily intervals over the 2 days before sponge removal, twice daily for the next 2 days, then at hourly intervals from 09:00 to 17:00 $\mathrm{h}$ for 2 days and then twice daily for a further 2 days, for measurement of plasma progesterone and the PGF metabolite 13,14-dihydro-15-keto-PGF (PGFM) by radioimmunoassay. Intermittent surges in plasma PGFM concentrations were observed in hourly samples collected from $4 / 4$ untreated females but in only $2 / 6$ of the inhibitor-treated females $(P<0.05)$, and the peak plasma PGFM concentrations were reduced in these 2 inhibitor-treated goats compared with the control goats. The corpora lutea $(C L)$ of the inhibitor-treated females appeared to be functional as indicated by the plasma progesterone profile and endoscopic examination of CL. In the control females, however, there was evidence of premature regression of CL. These results suggest that the premature release of PGF-2 $\alpha$ may be the cause of premature regression of CL in nanny goats induced to superovulate.
\end{abstract}

Keywords: corpus luteum; goat; prostaglandin; superovulation; progesterone

\section{Introduction}

Regression of corpora lutea within 6 days of superovulation in goats (Armstrong et al., 1982) and sheep (Ryan et al., 1987) is a major problem in embryo transfer programmes because it results in low rates of embryo recovery (Armstrong et al., 1983a). The cause of early luteal regression in animals of these species after superovulation has not been elucidated. In contrast, the endocrine control of luteal regression at the end of the natural oestrous cycle in sheep and goats is now well documented. Surges in the concentration of prostaglandin (PG) F-2 $\alpha$ in utero-ovarian venous plasma or its metabolite 13,14-dihydro-15-keto PGF-2 $\alpha$ (PGFM) in jugular venous plasma have been detected in ewes during the regression of the corpora lutea (Peterson et al., 1976; Flint \& Sheldrick, 1983; Hooper et al., 1986) and exogenous PGF- $2 \alpha$ can induce premature luteolysis (Goding, 1974). Administration of the inhibitor of PGF synthetase, indomethacin, can suppress uterine PGF-2 $\alpha$ release (Fairclough et al., 1987) and prolong the oestrous cycle in the sheep (Lewis \& Warren 1977) and goat (Cooke \& Homeida, 1984). Collectively these data indicate that uterine PGF-2 $\alpha$ plays a major role in luteolysis in the nanny goat and the ewe.

$\uparrow$ Present address: Human Reproduction Unit, Royal North Shore Hospital, St Leonards, New South Wales 2065, Australia. 
The present study was undertaken to investigate whether prostaglandins were the cause of the prematurely regressing corpora lutea in the superovulated nanny goat.

\section{Materials and Methods}

Animals. Oestrus was synchronized in 12 feral nanny goats of various ages by using intravaginal progestagen-impregnated sponges ( $60 \mathrm{mg}$ medroxyprogesterone acetate; Repromap, Upjohn, Melbourne, Australia) for 16 days. Superovulation was induced with 1200 i.u. PMSG (Pregnecol: Heriot Agvet, Melbourne, Australia), administered i.m. 2 days before sponge removal. The day of sponge withdrawal was designated as Day 0 .

Six females were injected with an inhibitor of prostaglandin synthetase, flunixin meglumine (Finadyne: Schering, Heriot Agvet, Melbourne) at a dose rate of $2.2 \mathrm{mg} / \mathrm{kg} / \mathrm{female} \mathrm{i.m.} \mathrm{at} \mathrm{12-h} \mathrm{intervals.} \mathrm{Treatment} \mathrm{began} \mathrm{at} \mathrm{07:00} \mathrm{h}, 3$ days after sponge removal and was continued for 4 days, finishing at $07: 00 \mathrm{~h}$ on Day 7 . The remaining females served as untreated controls.

The experiment was conducted in June 1987 and the animals were located at Rye, Victoria. Two goats from the control group were eliminated from the study; one doe did not superovulate and had no increase in the number of corpora lutea between Days 0 and 7 and the other had adhesions that prevented clear visualization of the ovaries at laparoscopy.

Blood samples. Blood was collected by jugular venepuncture, daily $(07: 00 \mathrm{~h})$ from 2 days before withdrawal of sponges, and twice daily (07:00 and 19:00 h) for 3 days thereafter. Blood was sampled hourly on Days 4 and 5 via an indwelling jugular catheter between $09: 00$ and $17: 00 \mathrm{~h}$. For the final 2 days, sampling continued at twice daily intervals. Blood was collected into heparinized tubes, centrifuged, and the plasma stored at $-20^{\circ} \mathrm{C}$ until assayed.

Laparoscopy. The ovaries of the goats were examined by laparoscopy under local anaesthesia on the day of sponge withdrawal to determine the incidence of premature ovulations (Battye $e t$ al., 1987) and again 7 days later to determine whether corpora lutea had regressed. Premature ovulations were defined as ovulations occurring before withdrawal of the progestagen-impregnated sponges.

Progesterone assay. Plasma progesterone concentrations were determined by radioimmunoassay using a direct solid-phase ${ }^{125}$ I assay (Coat-a-Count: Diagnostic Products Corporation, Los Angeles, CA, U.S.A.). The sensitivity of the assay system is $0.05 \mathrm{ng} / \mathrm{ml}$ and cross-reactivity with other steroids is $<1 \%$, except for 11 -deoxycortisol $(2.4 \%)$ and $20 \alpha$-dihydroprogesterone ( $2 \cdot 0 \%$ ). The inter- and intra-assay coefficients of variation samples were respectively $23 \%$ and $11 \%$ for samples with low concentrations of progesterone $(0.36-1.13 \mathrm{ng} / \mathrm{ml}), 12.3 \%$ and $2.8 \%$ for medium concentrations $(4 \cdot 23-7.03 \mathrm{ng} / \mathrm{ml})$ and $11.8 \%$ and $2.7 \%$ for those with high concentrations $(13.9-22 \cdot 1 \mathrm{ng} / \mathrm{ml})$.

PGFM assay. Plasma PGFM concentrations were determined by radioimmunoassay (Fairclough \& Payne, 1975). The PGFM antiserum was raised in goats and the cross-reactivity for PGFM, 13,14-dihydro PGF-2 $\alpha, 15$-keto-PGF-2 $\alpha$ and PGF and $\mathrm{C}_{16}$ urinary metabolites of PGF were $100 \%, 0.5 \%, 20 \%,<0.1 \%$ and $<1 \%$ respectively. As the antiserum did not distinguish between 13,14-dihydro-15-keto-PGF-1 $\alpha$ and 13,14-dihydro-15-keto-PGF-2 $\alpha$, the results are expressed as PGFM equivalents. The sensitivity of the assay was $0.05 \mathrm{ng} / \mathrm{ml}$. The inter- and intra-assay coefficients of variation were $19.5 \%(n=6)$ and $18.9 \%$ respectively.

Statistical analysis. For Days 4 and 5 the mean and s.d. of PGFM basal values were calculated for each goat by using a modification of the method described by Hooper $e t$ al. (1986). Briefly, peaks were identified if the concentration of a sample value was $3 \times$ s.d. above the mean basal concentration. Each basal mean and s.d. were calculated by (1) calculating the mean and s.d. of all samples for 1 day, (2) eliminating from further calculation values greater than the mean $+2 \times$ s.d., and (3) recalculating a new mean and s.d. from the remaining sample values for that day. This method was continued until no new sample values were eliminated. The resultant mean and s.d. was the basal concentration on that specific day.

PGFM values were identified as significant peaks if they were (1) greater than the mean basal concentration + $3 \times$ s.d., and (2) separated from another significant value by a basal value or a significant value that was greater than 3 s.d. below adjacent peaks. In animals in which there was only one reading above the sensitivity of the assay, this value was considered a peak only if it was $4 \times$ s.d. above the mean basal concentration for that specific day.

The incidences of premature ovulations, regression of corpora lutea and occurrence of PGFM peaks were analysed using G tests (Sokal \& Rohlf, 1981). Progesterone concentrations and PGFM peak values were compared by using a Mann-Whitney U test (Siegel, 1956). Frequency of PGFM peaks was analysed by a Wilcoxon Rank test (Diem \& Lentner, 1970). Results presented in the text are given as the mean \pm s.e.m.

\section{Results}

\section{Laparoscopic observations}

Premature ovulations. Between 1 and 3 corpora lutea per female were observed at laparoscopy in $7 / 10$ goats on Day 0, before progestagen sponge withdrawal. All 10 females superovulated after sponge removal. The ovulatory response is presented in Table 1. 
Corpus luteum regression. Regression of corpora lutea had occurred in all 4 control females at laparoscopy 7 days after sponge removal. All the corpora lutea of the 6 females treated with flunixin meglumine were morphologically normal at Day 7 (Table 1).

Table 1. Ovulatory response and luteal regression in goats treated with PMSG alone (control) or followed by treatment with flunixin meglumine

\begin{tabular}{|c|c|c|c|c|c|c|}
\hline & \multirow[b]{2}{*}{$\mathbf{N}$} & \multirow{2}{*}{$\begin{array}{c}\text { Females with } \\
\text { premature } \\
\text { ovulations }\end{array}$} & \multirow{2}{*}{$\begin{array}{l}\text { Females } \\
\text { super- } \\
\text { ovulating }\end{array}$} & \multirow{2}{*}{$\begin{array}{c}\text { Females with } \\
\text { with regressed } \\
\text { CL }\end{array}$} & \multicolumn{2}{|c|}{ No. $($ mean \pm s.e.m.) of ovulations } \\
\hline & & & & & $\begin{array}{c}\text { Before sponge } \\
\text { withdrawal }\end{array}$ & $\begin{array}{l}\text { After sponge } \\
\text { withdrawal }\end{array}$ \\
\hline Control & 4 & 4 & 4 & 4 & $1 \cdot 3 \pm 0 \cdot 3$ & $5 \cdot 8 \pm 1 \cdot 3$ \\
\hline Treated & 6 & 3 & 6 & 0 & $1.7 \pm 0.7$ & $8 \cdot 2 \pm 0.9$ \\
\hline
\end{tabular}

(a)
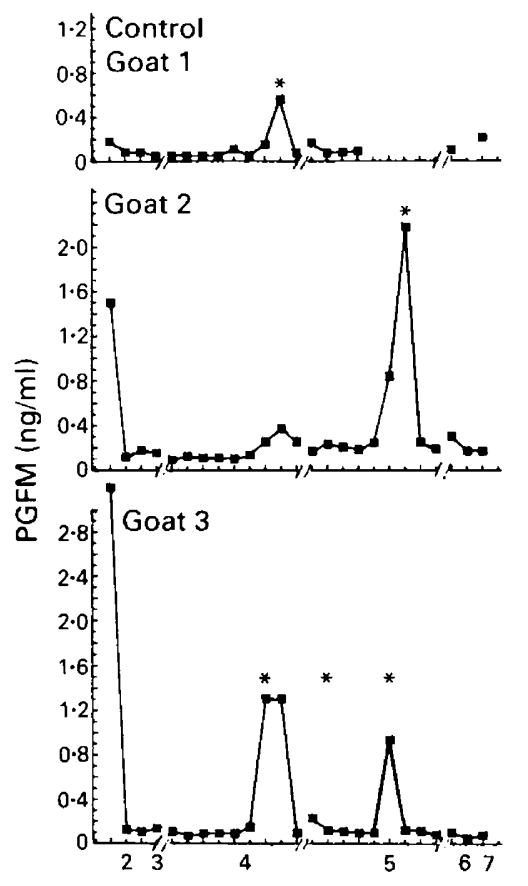

(b)
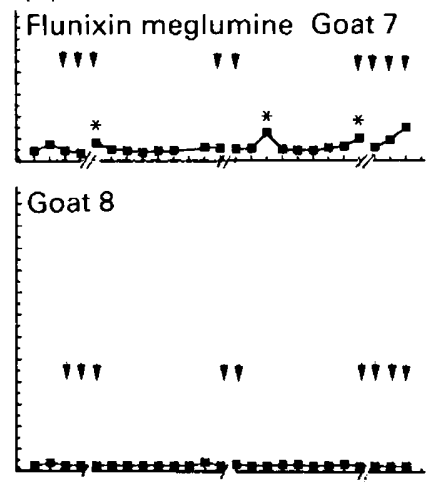

Goat 9

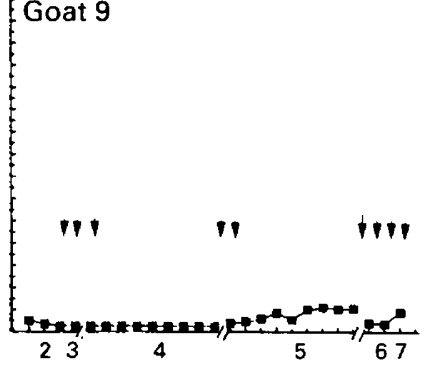

Days relative to sponge removal

Fig. 1. PGFM concentrations in (a) 3 control goats and (b) 3 goats given i.m. injections of flunixin meglumine (arrow heads). Plasma samples were collected every hour (09:00-17:00) on Days 4 and 5. *Significant peaks of PGFM.

\section{PGFM secretion}

Peaks of PGFM in the peripheral circulation were detected in all control does on Days 4 or 5 or both but only 2 of the 6 females treated with flunixin meglumine showed significant peaks in PGFM concentrations on these days $(P<0.05)$. PGFM peak concentrations were significantly higher $(P<0.05)$ in the control group $(0.88 \pm 0.31 \mathrm{ng} / \mathrm{ml})$ compared to the flunixin meglumine- 
treated does $(0.25 \pm 0.05 \mathrm{ng} / \mathrm{ml})$. Peak frequency over the 2-day sampling period was not significantly different between treatments although there was a trend towards a higher frequency in the control animals $(0.75 \pm 0.25$ and $0.33 \pm 0.25$ peaks per female per day (see Fig. 1)).

\section{Progesterone secretion}

Premature ovulation. Mean progesterone concentrations in females with premature ovulations were $0.30 \pm 0.05$ and $1.08 \pm 0.11 \mathrm{ng} / \mathrm{ml}$ on Days 0 and 1 respectively whilst the progesterone concentrations in females which had not prematurely ovulated were $0.08 \pm 0.04$ and $0.17 \pm 0.05 \mathrm{ng} / \mathrm{ml}$ over the same time period. The progesterone concentrations for these 2 days were significantly higher $(P<0.05)$ in females with premature ovulations compared to does that had not prematurely ovulated.

Superovulation. Concentrations of plasma progesterone in the goats treated with flunixin meglumine rose from Day 2, and were still increasing at the completion of the experiment (Fig. 2). In contrast, the progesterone profiles of 2 control females (Nos $2 \& 3$ ) showed a transient rise over Days $2-5$ but declined to basal level by Day 6 . In the other 2 control females plasma progesterone concentrations were initially high, reaching maxima of $15.4 \mathrm{ng} / \mathrm{ml}$ on Day 5 (No. 1) and $17 \cdot 1 \mathrm{ng} / \mathrm{ml}$ on Day 6 (No. 4, not shown), but had fallen by Day 7 to 1.3 and $8.1 \mathrm{ng} / \mathrm{ml}$ respectively. This is indicative of the onset of corpus luteum regression and was supported by the laparoscopic observations. The mean plasma progesterone concentrations were significantly higher $(P<0.05)$ in treated females than the controls for Days 4, 5,6 and 7, suggesting that luteal regression in control does had begun about Day 3-4.

\section{Discussion}

The results of this study present two lines of evidence for the involvement of prostaglandins in early luteal failure in the superovulated goat. First, pulses of PGFM were identified in untreated females in which the corpora lutea had regressed by Day 7 (Fig. 1). The mean PGFM peak concentration $(0 \cdot 88 \pm 0.31 \mathrm{ng} / \mathrm{ml})$ over Days 4 and 5 in these superovulated goats was slightly higher than that reported by Cooke \& Homeida (1984) during luteolysis in the naturally cycling goat. They reported PGFM peak concentrations of $\sim 0.6 \mathrm{ng} / \mathrm{ml}$ on Day 14, after which progesterone levels started to decline. Second, the administration of flunixin meglumin, an inhibitor of prostaglandin synthetase, prevented luteal regression. Presumably this was a consequence of the abolition of PGFM peaks in 4 of the 6 treated females, and significant reduction in peak concentration in the remaining 2 .

Although plasma PGFM peaks were observed in all 4 control females on Day 4 or 5 or both, it appeared that regression had begun as early as 3-4 days after sponge removal in the majority of animals. The concentration of plasma progesterone had declined in $3 / 4$ control females by Day 5 and in the fourth by Day 6. Furthermore, very high concentrations of PGFM were detected on Day 2 in two of the control females (Fig. 1). In a concurrent experiment we observed avascular corpora lutea 4 days after sponge withdrawal in superovulated does (unpublished observations). Most ovulations occur 36-60 h after sponge removal in PMSG-stimulated goats (Battye et al., 1987). It appears, therefore, that regression of the corpora lutea can occur within 2 days of their formation.

The comparatively high progesterone concentrations found on Day 0 in the females with premature ovulations raise the possibility that progesterone may be involved in early luteal failure. In the naturally cycling goat progesterone concentrations are at undetectable basal concentrations on Days 0 and 1 (Sutherland, 1987), in contrast to the levels in females with premature ovulations in our study. Progesterone administration to ewes in the first 3 days after oestrus induces the early release of PGFM and oxytocin, and as a consequence shortens the luteal phase (Ottobre $e t$ al., 


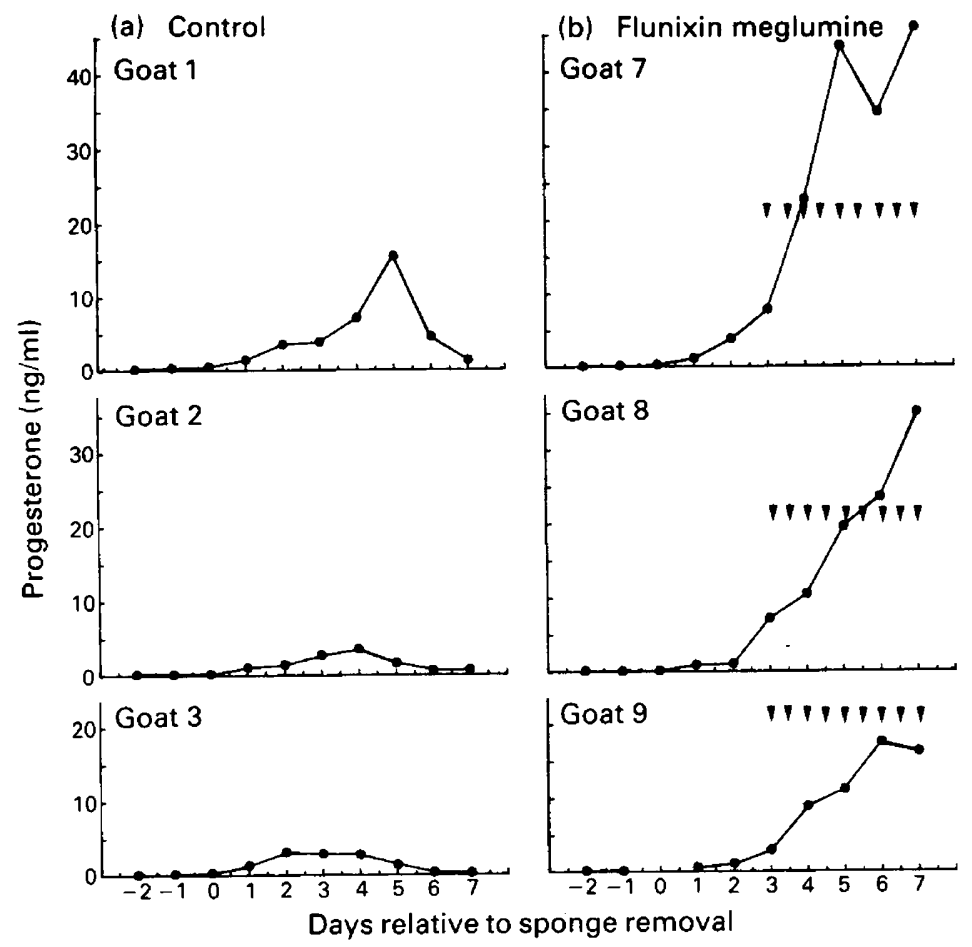

Fig. 2. Progesterone profiles of (a) 3 controls goats and (b) 3 goats given i.m. injections of flunixin meglumine (arrow heads).

1980; Peterson et al., 1986; Fairclough \& Peterson, 1986). It is possible, therefore, that progesterone, present because of premature ovulations, may advance the maturation of the uterine PGF- $2 \alpha$ secretory system, thereby inducing early luteal failure.

Another possible explanation for early luteal regression is that there may be a prolonged release of prostaglandins after sponge withdrawal. Smith et al. (1979) reported an intermittent surge in plasma PGFM release after progestagen sponge withdrawal in cattle and Kindahl et al. (1980) observed a prolonged release of prostaglandins when subcutaneous progesterone implants were inserted on Day 12 of the oestrous cycle in cows. In goats, therefore, prostaglandin release may be initiated at sponge withdrawal and maintained as a result of the low levels of progesterone secreted by the corpora lutea derived from premature ovulations. This mechanism in consistent with the elevated concentrations of PGFM detected at Day 2 in Goats 2 and 3 (Fig. 1).

Oestrogens may also play a role in early luteal failure. In the superovulated goat plasma concentrations of oestradiol increase within $24 \mathrm{~h}$ of PMSG injection and reach peak levels 7 days after injection (Armstrong et al., 1982). Armstrong et al. (1983b) reported that PMSG, compared to FSH, produced a longer stimulation of oestrogen secretion when used to induce superovulation and that luteal failure was significantly higher in the PMSG-treated goats. Ham et al. (1975) reported that oestrogens play a role in regulating the uterine PGF-2 $\alpha$ synthetase system and this may be mediated by oxytocin as oestrogen can induce the development of oxytocin receptors in the endometrium. The oestrogen-induced rise in endometrial oxytocin receptor concentrations may provoke an increase in oxytocin-induced PGF-2 $\alpha$ response as suggested by Roberts et al. (1976). It is possible, therefore, that PMSG-induced increases in plasma oestrogen concentrations may lead to an increase in the development of oxytocin receptors in the uterus much earlier than in the naturally cycling animal, permitting an oxytocin-induced release of PGF- $2 \alpha$. 
This work was supported by Embryotechnology Australia Pty Ltd and the Australian Wool Corporation and was carried out at Embryotechnology's Research Station, Rye, Victoria. We thank Mr A. Merret for assistance during the conduct of this experiment.

\section{References}

Armstrong, D.T., Pfitzner, A.P., Porter, K.J., Warnes, G.M., Janson, P.O. \& Seamark, R.F. (1982) Ovarian responses of anoestrous goats to stimulation with pregnant mare serum gonadotrophin. Anim. Reprod. Sci. 5, 15-23.

Armstrong, D.T., Pfitzner, A.P., Warnes, G.M. \& Seamark, R.F. (1983a) Superovulation treatments and embryo transfer in Angora goats. J. Reprod. Fert. 67, 403-410.

Armstrong, D.T., Pfitzner, A.P., Warnes, G.M., Ralph, M.M. \& Seamark, R.F. (1983b) Endocrine responses of goats after induction of superovulation with PMSG and FSH. J. Reprod. Fert. 67, 395-401.

Battye, K.M., Cameron, A.W.N. \& Trounson, A.O. (1987) Time of ovulation in goats treated with PMSG. Proc. Aust. Soc. Reprod. Biol. 19, 40, Abstr.

Cooke, R.G. \& Homeida, A.M. (1984) Delayed luteolysis and suppression of the pulsatile release of oxytocin after indomethacin treatment in the goat. Res vet. Sci. 36, 48-51.

Diem, K. \& Lentner, C. (1970) Scientific Tables. CibaGeigy Ltd, Basle.

Fairclough, R.J. \& Payne, E. (1975) Radioimmunoassay of 13,14-dihydro-15-keto-prostaglandin $F$ in bovine peripheral plasma. Prostaglandins 10, 266-272.

Fairclough, R.J. \& Peterson, A.J. (1986) Premature activation of the oxytocin-provoked uterine prostaglandin $F_{2 a}$ response in ewes given progesterone early in the oestrous cycle. Proc. Endocr. Soc. Aust. 29, Abstr. 33.

Fairclough, R.J., Moore, L.G., Peterson, A.J., Tervit, H.R. \& Watkins, W.B. (1987) Effect of systemic and intrauterine injections of indomethacin on plasma oxytocin-neurophysin concentrations in ewes over the time of normal corpus luteum regression. Biol. Reprod. 36, 543-548.

Flint, A.P.F. \& Sheldrick, E.L. (1983) Evidence of a systemic role for ovarian oxytocin in luteal regression in the sheep. J. Reprod. Fert. 67, 215-229.

Goding, J.R. (1974) The demonstration that PGF $_{2 a}$ is the uterine luteolysin in the ewe. J. Reprod. Fert. 38, 261-271.

Ham, E.A., Cirillo, V.J., Zanetti, M.E. \& Kuehl, F.A., Jr (1975) Oestrogen-directed synthesis of specific prostaglandins in uterus. Proc. natn. Acad. Sci. U.S.A. 72, 1420-1424.

Hooper, S.B., Watkins, W.B. \& Thorburn, G.D. (1986) Oxytocin, oxytocin-associated neurophysin, and prostaglandin $\mathrm{F}_{2 a}$ concentrations in the utero-ovarian vein of pregnant and non pregnant sheep. Endocrinology 119, 2590-2597.

Kindahl, H., Edqvist, L-E. \& Lindell, J-O. (1980) On the control of Prostaglandin release during the bovine oestrous cycle. Adv. Prostaglandin Thromboxane Res. 8, 1351-1355.

Lewis, P.E. \& Warren, J.E., Jr (1977) Effect of indomethacin on luteal function in ewes and heifers. $J$. Anim. Sci. 46, 763-767.

Ottobre, J.S., Lewis, G.S., Thayne, W.V. \& Inskeep, E.K. (1980) Mechanism by which progesterone shortens the oestrous cycle of the ewe. Biol. Reprod. 23, 1046-1053.

Peterson, A.J., Tervit, H.R., Fairclough, R.J., Havik, P.G. \& Smith, J.F. (1976) Jugular levels of 13,14dihydro-15 keto-prostaglandin $\mathrm{F}$ and progesterone around luteolysis and early pregnancy in the ewe. Prostaglandins 12, 551-558.

Peterson, A.J., Fairclough, R.J., Smith, J.F., Tervit, H.R., Moore, L.G. \& Watkins, W.B. (1986) Administration of progesterone early in the oestrous cycle causes premature release of PGFM and oxytocinneurophysin. Proc. Aust. Soc. Reprod. Biol. 18, 83, Abstr.

Roberts, J.S., McCraken, J.A., Gavagan, J.E. \& Soloff, M.S. (1976) Oxytocin stimulated release of prostaglandin $\mathrm{F}_{2 a}$ from ovine endometrium in vitro: correlation with estrous cycle and oxytocin receptor binding. Endocrinology 99, 1107-1114.

Ryan, J.P., Maxwell, W.M.C. \& Hunton, J.R. (1987) Factors affecting the incidence of prematurely regressing corpora lutea in superovulated ewes. Proc. Aust. Soc. Reprod. Biol. 19, 69, Abstr.

Siegel, S. (1956) Nonparametric Statistics for the Behavioral Sciences. McGraw-Hill, Kogakusha, Ltd, Tokyo.

Smith, J.F., Fairclough, R.J. \& Peterson, A.J. (1979) Plasma levels of progesterone, Provera, oestradiol$17 \beta$ and 13,14-dihydro-15 keto-prostaglandin $F$ in cows treated with Provera-impregnated intravaginal sponges. J. Reprod. Fert. 55, 359--364.

Sokal, R.R. \& Rohlf, F. J. (1981) Biometry, 2nd edn. W.H. Freeman \& Co., San Francisco.

Sutherland, S.R.D. (1987) Progesterone concentration and pulsatile LH secretion during normal oestrous cycles in Angora-cross does. Proc. 4th Animal Sci. Congress (Asian-Australasian Association of Animal Production Societies), p. 246, Abstr.

Received 19 January 1988 